\title{
The ARCHIVES OF ARTAXATA: ArChIVAl PRACTICE IN THE CAPITAL OF ANCIENT ARMENIA ${ }^{1}$
}

\author{
Torben Schreiber \\ iD http:/orcid.org/0000-0002-8442-9554 \\ Westfälische Wilhelms-Universität Münster \\ Institut für Klassische Archäologie und Christliche Archäologie
}

\begin{abstract}
This article examines the seal impressions from Artaxata discovered in 1979/80 during excavations carried out by the Armenian Academy of Sciences on Hills V and VIII. As the archive on Hill VIII is quite small with only 20 to 25 seal impressions, the focus of this paper lies on the approximately 8,000 seal impressions found on hill $\mathrm{V}$. The complex was dated to the period from $180 \mathrm{BC}$ to $59 \mathrm{AD}$ and it was assumed that it was a "private" archive or a kind of "chancellery." An analysis of the finds in a wider context and the comparison with other archival complexes of the Hellenistic period as well as an examination of the characteristic features of "official" seals (size, image, shape, number of impressions) leads to the conclusion that it must have been a public archive, most probably it is the city archive of Artaxata.
\end{abstract}

Keywords: Hellenistic, Archives, Seals, Sealings, Armenia, Artaxata.

The archives or - more accurately put — the seal impression inventories of Artaxata were found during field campaigns conducted by the Armenian Academy of Sciences in the years $1979 / 1980 .^{2}$ A low number of 20 to 25 impressions was found on Hill VIII on the clay floor of a small room within a house. ${ }^{3}$ Unfortunately, their precise find spot is not indicated in the published maps. Many more items were discovered on hill V. The assemblage there consists of 8,000 impressions, of which ca. 6,000 are in a readable

1 I would like to thank the organizers of the conference "Ancient Armenia in Context"-A. Lichtenberger and G. Traina - for the kind invitation and the chance to give the present paper. I would also like to warmly thank M. Zardaryan for his support regarding access to the material discussed here and important information pertaining to the localization of the archives. And last but not least I would like to thank S. Whybrew for reviewing and proofreading the manuscript.

2 E.g. Manoukian 1996, 371.

3 Khachatrian - Neverov 2008, 246; Khachatrian 1996a, 366. 
condition. ${ }^{4}$ In this case the location is clearly described (Maps 1, 2): The sealings were found in a nearly rectangular room and a corridor, which appear to have been part of a larger housing complex. This complex lies about $20 \mathrm{~m}$ to the east of one of the gates of the city's fortification wall. Between the gate and the building is a courtyard-like space. Most of the sealings were recovered from a $10-15 \mathrm{~cm}$ thick ash-layer. Coins from the times of Tigranes II and Augustus, some copper coins from Antioch and ceramics date the sealings - i.e. the destruction layer of the archive - to the first period of Artaxata from $180 \mathrm{BC}$ to $59 \mathrm{AD}$. The smaller archive is also said to date from this period. ${ }^{5}$

In 2013 another archive was discovered with over 600 impressions dating from the 4th century BC to the 3rd century AD in the area of the "Riverside District." With this very long duration - of over 600 years - this still unpublished archive complex would be entirely unique. Even archives with an occupational period of three or four hundred years constitute exceptions. ${ }^{7}$ Usually, the "active lifespan" of a Hellenistic archive estimated to be between one hundred to one hundred and fifty years. This applies at least to the complexes of Callipolis, ${ }^{8}$ Seleuceia on the Tigris ${ }^{9}$ and Orchoi ${ }^{10}{ }^{1}$ which must be used as points of reference as they are well published, while other complexes are still inaccessible. ${ }^{11}$ However, in order to be able to make a final assessment of the archive complex of the "Riverside District," a complete examination of the material must be carried out, since the use of a seal bearing the portrait of Alexander the Great does not provide an adequate basis to date the entire complex to the Hellenistic period. ${ }^{12}$

Since the large complex on Hill $\mathrm{V}$ is the most extensively investigated so far and the material is accessible, the focus of this article lies on the sealings found there.

\section{Some General Remarks on Seal Impressions}

As the terminology pertaining to seals is always a little bit confusing, ${ }^{13}$ it is important to give a short overview on the terms used (Fig. 1): the (lost) document was closed with a sealing. This sealing carried a seal impression, which was impressed by a seal. The original seal is almost always lost. ${ }^{14}$

4 Khachatrian - Neverov 2008, 246; Khachatrian 1998, 135; Khachatrian 1996a, 365-366.

Khachatrian - Neverov 2008, 245-246; Khachatrian 1996a, 365-366; for the city's history cf. e.g. Tonikian 1992.

6 Zardaryan 2020, 310.

7 Carthage: Berges 1997; Cyrene: Maddoli 1965; Dura Europos: Leriche 1996; Zeugma: Önal 2018.

8 Pantos 1985.

9 Invernizzi et al. 2004, I-III.

10 Lindström 2003.

11 Lesperance 2010, 31-65 with the most recent overview on Hellenistic archives attested through sealings; cf. Coqueugniot 2013 with an evaluation also of the historical sources.

12 See Zardaryan 2020, 310 with fig. 11, 3.

13 Cf. Lindström 2003, 7; Berges 1997, 11-12.

14 Lilibaki-Akamati 2011, 70.104 with fig. constitutes, to my knowledge, the only exception. 
By now over 200,000 seal impressions are known from Hellenistic and Roman times. ${ }^{15}$ In Seleucia on the Tigris alone 30,000 impressions of Hellenistic seals were found, ${ }^{16}$ in Zeugma there are said to be more than 100,000 impressions. ${ }^{17}$ Until now more than 20 Hellenistic and Roman archives are attested through their sealings (Map 3) discovered more or less in their original contexts - and the inventories are usually only partly published. ${ }^{18}$ Considering the above mentioned numbers, it is hardly surprising that the publication of the material is usually delayed.

The seal impression inventories have only been preserved because the associated archives burned down. On the one hand, the fire led to the destruction of the archive buildings and destroyed the documents made of parchment and papyrus, on the other hand, the fire hardened and thus conserved the previously only air-dried clay-sealings, which would otherwise most probably have been lost. A seemingly paradox way of preservation.

Only in rare instances have papyri or parchments been preserved with the sealings still on them. These specimens stem mostly from Hellenistic and Roman Egypt, where climatic conditions permitted their preservation. ${ }^{19}$ From these completely preserved documents we know that the names of the individuals sealing them were often written beneath or next to the seal impressions. Some of the texts also mention the function in which a person using a seal was involved in the archival process and which motif the person's seal bore. Preserved papyrus texts from Roman times describe very precisely who sealed and which seal was used, thus ensuring clear identification of the persons involved and also preventing forgeries of contracts. ${ }^{20}$

However, due to the described process, the finds to be considered here have been de-contextualised in two ways: the archive building was usually destroyed and the document - once bearing the sealing with its impressions - is nearly always lost. This means that information about the sealings must be drawn from the finds themselves, as there are hardly any external indications for the classification of these seal impression inventories and the documents that they once sealed. ${ }^{21}$

The sheer volume of finds, which requires an enormous amount of time to process, and the few results to be expected from their analysis has led to the material being rather neglected. Instead, time and time again, a small number of examples clearly identifiable as 'official' seals on the basis of their inscriptions have been singled out. ${ }^{22}$

15 On the current state of the art: van Oppen, Wallenfels, forthcoming; for an overview that is still largely up-to-date cf. Boussac - Invernizzi 1996.

16 Invernizzi et al. 2004, I.

17 Önal 2018, VIII.

18 For the most recent overview cf. Lesperance 2010, 31-65.

19 E.g. Vandorpe 1996; Rubensohn 1907.

20 E.g. Corpus Papyrorum Raineri 6, No. 1. Harrauer - van Lith 1978, 13-18. Cf. Plantzos 1999, 21 note 27.

21 Regarding the reconstruction of the content of the documents, cf. e. g. Messina, forthcoming; Lindström 2003, 11-12.

22 Regarding the definition of official seals, c. f. e.g. Invernizzi et al. 2004, I: 25-30; Lindström 2003, $25-26$. 
The sealing process can easily be reconstructed from the preserved sealings. ${ }^{23}$ Basically, a distinction is made between two sealing practices: the cuff-shaped technique, which is reminiscent of napkin rings, and the lump-of-clay sealing. Both have been referred to by scholars as 'Bullae'. The first form is not known from Artaxata and is limited to Mesopotamia. ${ }^{24}$

In Artaxata only sealings of the second type are known so far. The sealing process was as follows: First, the already written document was rolled up (1) and an elongated piece of clay was laid on top (2). Now the document and half of the clay strip were wrapped with a string (3). The half that had not been wrapped was then folded over the string and smeared by hand to form a lump (4). Finally, one or more seals were pressed into the clay (5). Most sealings from Artaxata show only one impression. Only 114 were stamped more than once. ${ }^{25}$ Sealings exhibiting multiple seal impressions can be assumed to stem from contracts or other documents which needed to be ratified by at least two parties and in some cases by witnesses, such as wills, sales contracts or the like. ${ }^{26}$

It is also possible that a document was wrapped by several strings and thus closed by more than one sealing. ${ }^{27}$ That means, that also sealings bearing only one seal impression could have been applied to contracts and not only to letters. Due to this fact we are not able to determine, how many documents were stored within a single archive. Such a number can at most be estimated, when the context is rather straightforward and well documented. ${ }^{28}$

Depending on the writing material used, the backs of the sealings are either smooth or show impressions of papyrus fibres. ${ }^{29}$ Many pieces still preserve the string channels. Once a document had been sealed, it was no longer possible to open the document without damaging the string or the sealing.

\section{The Archive of Artaxata in Previous Research}

The material from Artashat was published by Z. Khachatrian, H. Manoukian and O. Neverov in three articles in the important supplement 29 of the Bulletin de Correspondance Hellénique published by M.-F. Boussac and A. Invernizzi as the results of a conference held in Torino. ${ }^{30}$ Some of the sealings were also part of an exhibition in Nantes in $1996^{31}$ and Khachatrian mentioned the sealings in his contribution to the book of Invernizzi "Ai piedi dell'Ararat." 32 The most important publication is the catalogue

\footnotetext{
23 E.g. Lindström 2003, 9-11 with fig. 2; Berges 1997, 14-17 with fig. 1.

24 See Lindström 2003, 8-11.

25 Khachatrian - Neverov 2008, 246.

26 Cf. Vandorpe 1996, 232-240.

27 E.g. Winn Leith 1998, pl. 22; Vandorpe 1996, pl. 46, fig. 7; Rubensohn 1907, pl. 1.

28 E.g. Messina, forthcoming.

29 E.g. Schreiber 2019a, 230-231 with fig. 2.

30 Khachatrian 1996a; Manoukian 1996; Neverov 1996.

31 Khachatrian 1996b.

32 Khachatrian 1998.
} 
from 2008 by Khachatrian and Neverov ${ }^{33}$ which has eluded the attention of many scholars even though Neverov and Khachatrian have made the archive inventory accessible to the scientific community.

Following the work that has been conducted on the sealings so far, the results can be summarized as follows:

The seals used in Artaxata were of round, rectangular, triangle and oval shape. It has been suggested that the impressions come from seals made of precious or semi-precious stones and metal. On the backsides one to six holes for the string that was wrapped around the document can be observed. The more than 6,000 readable impressions come from 1,035 seals. 30 of them exhibit an inscription or a monogram sometimes associated with an image, sometimes without. ${ }^{34}$ Based on their style, the seals came from various regions: from Crimea in the north, Egypt in the south, Rome in the west and Parthia in the east. ${ }^{35}$ The images on the seals include: kings, ${ }^{36}$ motives of flora and fauna, theatre scenes, portraits etc. ${ }^{37}$ One of the most striking specimens depicts a row of prisoners (Fig. 2).

We also find chariots, hunting scenes, depictions of Median people, Persians and animals such as deer, lions, and boars. ${ }^{38}$ The inventory of seal impressions appears to be indicative of the Armenian capital's status as a "intermediary." Some seals bear motives used in the "west," other images are indicative of an "eastern" influence.

Some of the depictions have been connected to the Roman civil war in the third quarter of the 1st century BC. ${ }^{39}$ Although this might be straining the evidence, the composition of this archive-inventory with its wealth of representations of different origins seems to be unique among the Hellenistic archives known so far. The large archive of Seleucia on the Tigris for example with its over 6,000 attested seals shows a much more homogeneous picture with a preponderance of Greek-Hellenistic motifs. ${ }^{40}$

Concerning the general character of the larger archive in Artaxata, Manoukian and Khachatrian came to the conclusion, that the archive is more likely of a private character. If it was an official archive, they argued that it would more probably have been located on Hill II close to other public and royal buildings. It is also most likely no temple archive, because the religious centre of the city is to be found on Hill VI. ${ }^{41}$ Khachatrian states that temple archives, royal archives and tax archives in Armenia are known from literary sources of the 5th century. ${ }^{42}$ And, of course, we have to expect private and official archives in a city with approximately 100.000 inhabitants. Artaxata was a large and important commercial centre and sealings from the 8th and 7th century are known from Teishebai, Van and Bastam. ${ }^{43}$ Sealings from the 5 th and 4 th century come from Armavir

\footnotetext{
33 Khachatrian - Neverov 2008.

34 Khachatrian - Neverov 2008, 245-251.

35 Khachatrian - Neverov 2008, 251; Khachatrian 1996a, 368.

36 Neverov 1996, 375-376.

37 Khachatrian - Neverov 2008, 248 and the catalogue Khachatrian - Neverov 2008, 133-244 with pls.

38 E.g. Khachatrian 1996a, 367 pls. 73-76; Manoukian 1996, 372 with pls. 79-81.

39 Khachatrian - Neverov 2008, 248; Khachatrian 1998, 137; Khachatrian 1996a, 367-368.

40 Cf. Invernizzi et al. 2004, I-III.

41 Khachatrian 1996a, 368; Khachatrian 1996b, 222; Manoukian 1996, 371.

42 Khachatrian - Neverov 2008, 250; Khachatrian 1996a, 368.

43 Khachatrian - Neverov 2008, 250 with note 7.
} 
and Sassanian and later seals are known from Dvin ${ }^{44}$ and now also from Artaxata. Consequently, the seal impressions from Artaxata are clearly part of a regional tradition, as we know it from other areas of the Mediterranean world, which extends beyond the period considered here. ${ }^{45}$

The fact that the great archive in Artaxata seems to have been housed in a dwelling in a non-official part of the city, the small number of the official seals and the absence of tax seals, ${ }^{46}$ has led to the conclusion that the archive was a 'private' one. Manoukian also states, that it could have been a sort of chancellery, where the incoming letters and/ or goods were stored for some time. ${ }^{47}$

\section{The Archive of Artaxata Reconsidered}

What can one conclude from the location and the architectural context through a comparison to other public and "private" archives? To answer this question, a closer look at archives whose public character is evident is necessary. Such archives certainly had a public function as they contained either tax seals and/or other seals with inscriptions naming offices, ${ }^{48}$ institutions ${ }^{49}$ and/or cities. ${ }^{50}$ The seal impressions discovered in the large archive of Seleucia on the Tigris ${ }^{51}$ as well as the archives of Kydissos, ${ }^{52}$ Doliche, ${ }^{53}$ Nea Paphos, ${ }^{54}$ Pella, ${ }^{55}$ Gitana, ${ }^{56}$ Selinus $^{57}$ and Cyrene ${ }^{58}$ attest the existence of public archives in those cities. In the cases of Dura Europos and Cyrene, inscriptions refer to the buildings as "Chreophylakeion" 59 or "Nomophylakeion." 60

Only the buildings in Seleucia on the Tigris, Cyrene and Dura Europos can be typologically described as archive buildings. These buildings contain rooms intended for the storage of documents which can be recognised as such even today. ${ }^{61}$ The archive of Doliche has not yet been precisely located, but it is certain that it was located in the public space of the city - the Agora or Forum - and the seals used here prove, that it

44 Khachatrian - Neverov 2008, 250 with note 8 .

45 Lists of archives: Lesperance 2010, 31-65; Berges 1997, 33-38; Weiß 1992, 171-193; Klose 1984, 63-76; Salzmann 1984, 164-166.

46 Khachatrian - Neverov 2008, 250; Khachatrian 1996a, 368.

47 Manoukian 1996, 371.

48 E.g. "Chreophylakes": Invernizzi et al. 2004, I, 39-40, No. Se 1-4. 6-7 with pl. 15.

49 E.g. "emporion of Pella": Killen 2017, 190 with pl. 13, 11.

50 E.g. Kydissos: Ariel - Naveh 2003, 72-74 with fig. 7.

51 Invernizzi et al. 2004, I-III.

52 Berlin - Herbert 2003, 46-54.

53 Schreiber 2019b.

54 Kyrieleis 2015, 15-16.

55 Lilibaki-Akamati 2011, 70.

56 Preka-Alexandris - Stoyas 2011, 677-681.

57 Zoppi 2011

58 Maddoli 1965.

59 Leriche 1996, 159-160.

60 Salzmann 1984, 141-144.

${ }^{61}$ Cf. Messina 2006; Salzmann 1984, 141-142; Leriche 1996, 161-163. 
must have been the city's main archive and thus public. ${ }^{62}$ The archive inventories of Nea Paphos and Selinus are known from destruction layers, used for the foundation of new buildings. ${ }^{63}$ So the architectural context cannot be reconstructed with any degree of certainty, but the inventories - as far as they are accessible - unambiguously demonstrate that official seals were used here.

The archives of Gitana and Kydissos could provide a decisive clue for the interpretation of the large archive assemblage of Artaxata, because both seal impression inventories were found in individual rooms of bigger complexes, which at first glance could be mistaken for residential buildings, but which in fact clearly are public buildings of the city administration. The excavators identified the building in Gitana as "Prytaneion" 64 and the building in Kydissos as a "Persian-Hellenistic-Administrative-Building." 65

In light of this, the fact that the archive was housed in a residential building is therefore indeed not a convincing argument for its identification as a private archive at all. Maybe we have a similar situation in Artaxata as in Kydissos or Gitana. It must be added here, that there are only three archives from Hellenistic times so far, which have been unambiguously interpreted as private archives. One is the archive of Aizanoi, ${ }^{66}$ which has only inadequately been processed so far, but which contains only about 50 seal impressions stemming from a Hellenistic private building. The others are the archives A and B uncovered in Seleucia on the Tigris within a Hellenistic housing complex. 126 impressions were discovered in archive A, while archive B yielded 105 impressions. ${ }^{67}$ a very small number compared to the assemblage from Artaxata.

There are also some archives which are said to be "somewhere in between" a 'private' and a public archive: the most prominent example might be the archive of Delos, discovered in what appears to be a 'private' home. ${ }^{68}$ Since the inventory clearly shows that documents sealed with official seals were stored there, ${ }^{69}$ I would suggest, that the archive was related to local administration and that the house was used by officials as their residence. An archive containing more than 20,000 seal impressions - and consequently thousands of documents - cannot be attributed to a private individual. Maybe it was the residence of the epimeletai. ${ }^{70}$

Comparing the number of impressions found in the known archive complexes, the archive of Artaxata falls quite exactly in the middle of those archives, which are to be unambiguously characterized as official (Fig. 3). This fact alone is, however, insufficient to determine the character of the Artaxata archive with a reasonable degree of certainty: it is, instead, necessary to take a closer look at the archive inventory and at every single impression. It is to be expected that the inventory of a public/official archive will contain a large number of impressions coming from official seals. The question then becomes: how can we identify these official seals in the large number of more than 6,000 impressions?

62 Schreiber 2019b.

63 Kyrieleies 2015, 3-4; Zoppi 2011, 29.

64 Preka-Alexandris 1996, 196-197.

65 Berlin - Herbert 2012, 28-29.

66 Berges 2010.

67 McDowell 1935.

68 Boussac 1992; Boussac 1988.

69 Boussac 1992, 11-18 with pls. 1-2.

70 Schreiber, forthcoming. 
In the scientific examination of the Hellenistic seal impression inventories and seals used, a fundamental distinction has been made between 'official' seals and so-called 'private' seals. $^{71}$ This distinction is of particular importance, as the function of the respective archive can be determined on the basis of the classification of the seal impressions found. According to many scholars, official seals are characterised by the following features: they are usually considerably larger than 'private' seals, ${ }^{72}$ often carry an inscription, ${ }^{73}$ are decorated with official images — particularly images that are also found on coins ${ }^{74}$ — and are thus of a higher quality ${ }^{75}$ than 'private' seals and are often preserved in multiple impressions. ${ }^{76}$

Literary sources may also provide clues for the identification of official seals, although so far only the seal of the Seleucid royal court, which sealed with an anchor, has been identified on this basis. ${ }^{77}$ Without the literary sources referring to the Seleucid anchor as the official seal of the Seleucid court, one would maybe not have recognised these impressions as coming from official seals. ${ }^{78}$

The most important/reliable identifying trait of an official seal are inscriptions naming an office, a city or a Koinon. ${ }^{79}$ Since this feature allows an unambiguous identification of an official seal, it must be given more weight than the other criteria mentioned. The tax seals also belong to this group, but since most of them carry inscriptions while lacking figurative representations ${ }^{80}$ they are of limited value for determining features that could be used to identify other official seals. Since there are official seals without inscriptions, the question arises: how can one identify an official seal when it has no inscription on it and there are no literary sources mentioning it?

Only a quantitative consideration of the clearly official seals can help here: there are only 105 adequately published seals with inscriptions from Hellenistic times ${ }^{81}$ that can be adduced for such an analysis. The result of this analysis is clear (Fig. 4).

In addition to the inscription or the depiction of the Seleucid anchor, these official seals are characterized by the fact that $99 \%$ of them are above average in size, $96 \%$ of them left a flat impression, $90 \%$ show an image repertoire indicating their official character-comparable to coin images - and the repeated use of $69 \%$ is attested through multiple impressions. ${ }^{82}$

A Hellenistic official seal thus appears to have been larger than average seals, have had a flat surface, very likely to have borne a motif already known from coinage and is probably attested in more than one impression.

71 E.g. Berges 2010, 39; Lesperance 2010, 61-65; Invernizzi et al. 2004, I: 25; Lindström 2003, 15. 25.

72 E.g. Killen 2017, 47; Lesperance 2010, 61; Invernizzi et al. 2004, I: 25; Lindström 2003, 25.

73 E.g. Killen 2017, 47; Berges 2010, 39; Lesperance 2010, 61-62; Invernizzi et al. 2004, I: 25; Ariel Naveh 2003, 61; Lindström 2003, 25.

74 E.g. Killen 2017, 47; Lesperance 2010, 61; Invernizzi et al. 2004, I: 25; Lindström 2003, 25. 49-51.

75 E.g. Lindström 2003, 25.

76 E.g. Berges 1997, 19-20.

77 App. Syr. 56, 286-287; Iust. 15.4.3-4; cf. Mittag 2006, 124-125 with note 136; Lindström 2003, 37-38 with note 241 ; Instinsky $1962,17-18$ with note 18-23.

${ }^{78}$ Cf. Invernizzi et al. 2004, I: 28-32 No. SU 1-19 with pls. 13-14. On official seals without inscriptions see also Schreiber 2020, 84-91.

79 Cf. the "epirotic league": Pantos 1985, No. 97.

80 Invernizzi et al. 2004, I: 3-24 with pls. 1-13; Lindström 2003, 51-58.

81 Most of them were found in Seleucia on the Tigris: Invernizzi et al. 2004, I: 25-32 with pls.

82 For the complete analysis see Schreiber, forthcoming. 
This characterisation allows the mass of seals to be sorted and the group of "seals with official character" to be filtered out of the mass. This approach allows a more objective access to the material and enables us to move beyond the tendency of previous studies of singling out exceptional pieces and attributing an official character to them on the basis of their outstanding artistic design. But this approach is only feasible when the material has been adequately processed. Thanks to Neverov and Khachatrian, the inventory of the archive of Hill V in Artaxata is available for such a study even if their catalogue unfortunately lacks some important information.

A detailed study of the iconographic repertoire cannot be undertaken here, but broadly speaking, the images on the seals relate to the following topics (although the subdivision into such groups cannot always be unambiguous) (Fig. 5). Our primary concern here is to characterize the archive as a whole. Therefore, a more general comparison with the themes attested on seals in Seleucia on the Tigris seems promising: In Seleucia, depictions of animals make up around 7\% of the repertoire (Fig. 6), in Artaxata, this group is the most prominent with a share of ca. $27 \%$. There are also a lot more portraits to be found on the seals from Seleucia, while the rest of the shares seem comparable. The differences that can be identified in detail require further examination.

29 of the seals bear monograms or inscriptions (some of them only single letters). There are six with monograms, five with Greek inscriptions and 18 with Aramaic inscriptions. The seals with Aramaic inscriptions mention names, but no offices or titles. One of these seals is, however, attested on 60 sealings. The Aramaic inscription identifies it as "[...] son's seal" 83 (Fig. 7). Furthermore, the size of this seal is remarkable. The seal measures 15 to $10 \mathrm{~mm}$, which makes it $5 \mathrm{~mm}$ larger in height than the average seals used in Artaxata (Fig. 8). None of the inscriptions so far-including those in Greek, most of which are in a bad condition - refer to official institutions. Consequently, there is no seal in the whole complex which can be connected to a city, an institution and/or officials via the inscriptions.

The average size of the seals used in Artaxata gleaned from the impressions is $10 \times 9 \mathrm{~mm}$. Compared to other archives, this is small.

$57 \%$ of the seals used have left a flat impression, $23 \%$ a concave impression and $20 \%$ are too poorly preserved to determine whether they were flat or concave (Fig. 9). These shares are very good comparable to other archives where the share of flat seals is always larger than that of concave ones. There are good reasons to assume that the bigger and flat impressions come from metal rings. ${ }^{84}$

Concerning the Artaxata archive, the combination of the characteristics size, flatness of the impression and repeated use can lead to a general characterisation of the whole inventory as an inventory of official character:

The catalogue lists 1,035 seals which were used 6,296 times. That means, that a single seal in Artaxata was used an average of 6.2 times (Fig. 10). Compared to other archives, this number is very high. In Seleucia on the Tigris a seal was used an average of 4.9 times - when excluding the tax seals. This makes Artaxata's large archive, the leader of this statistic.

If the consideration of the inscriptions does not lead to anything, only quantitative analysis remains as tool to search for specific features to filter out the official seals:

\footnotetext{
83 Khachatrian 1996a, 366.

84 See Schreiber, forthcoming.
} 
220 seals are above average in size. The largest is the already mentioned seal with the row of prisoners (Fig. 3). Size cannot be used to determine if it is an official seal, because as a cylinder seal it belongs to a group with a different average size. This seal is preserved in 27 impressions. It was dated back to the 5 th century BC by Khachatrian and Neverov, which means that the seal may have been in use for a very long time. ${ }^{85}$ As the evaluation of other archives shows, some of the official seals were in use for a long period. ${ }^{86}$ Of course, it is also possible that older documents from another archive were stored here. However, the motif of this seal indicates a certain official character making it less likely that it stems from a private context.

The other large seals show the head of Athena (Fig. 11), a lion protome (Fig. 12) attested in 46 impressions - , a Hermes (Fig. 13), deer(?) (Fig. 14), a horse and a deer (Fig. 15) - also known from 46 impressions-, two riders with spears (Fig. 16), a horse (Fig. 17) and a standing Tyche (Fig. 18).

Looking at the group of the most often used seals, one can see that 2,582 of the total of 6,296 impressions come from the 10 most frequently used seals (Fig. 19). This accounts for more than $40 \%$ of all seal impressions. The most often used seal bears the depiction of a pilos, which is preserved in 611 impressions (Fig. 20). It is followed by an image of a hand holding an ear of grain (Fig. 21). The next seal shows a female bust to the right (Fig. 22). Neverov identifies this figure as Aphrodite with an Eros and therefore maybe Cleopatra VII with Caesarion. ${ }^{87}$ But it is more likely an Artemis, because a quiver can be seen on her back and no Eros or child is, in fact, depicted here. Now one could consider that this seal depicts a Ptolemaic queen as Artemis, but it is already remarkably enough to see the strong Ptolemaic iconographical influence. ${ }^{88}$

Among the most frequently used seals we also find a Nike writing on a shield (Fig. 23), a theatre mask (Fig. 24), two mice on an ear of grain (Fig. 25), Eros and a deer (Fig. 26), a panther and a thyrsus (Fig. 27), the abduction of Ganymede (Fig. 28) and a king(?) sitting on a throne (Fig. 29).

All of these seals are rather average in size, but some of them come from seals with a flat surface, which might indicate an official character. Just to remember: $96 \%$ of the official seals with inscriptions from Hellenistic times had a flat surface (Fig. 3). This might be due to the fact that these seals were made of metal.

To put the Artaxata archive in a larger context: some of the seals that are preserved in impressions are amongst the most frequently used seals in antiquity or at least amongst those most frequently attested in impressions (Fig. 30).

There are three different explanations for this strikingly frequent use of seals:

1. they are official seals that we do not immediately recognize as such because they do not have an inscription. Here again the Seleucid anchor is to be mentioned as the most prominent example of that kind.

85 Khachatrian - Neverov 2008, 248; Khachatrian 1996a, 367.

86 E.g. Invernizzi et al. 2004, I: No Se 1 used for ca. 30 years; Invernizzi et al. 2004, I: No Se 39 might have been used for more than 80 years; see Schreiber, forthcoming.

87 Neverov 1996, 375.

88 Regarding the "Zeitgesicht" on the so-called Ptolemaic rings, see Schreiber 2016. 
2. these are not impressions of individual seals, but of several serially manufactured seals. $^{89}$

3. they are so-called lending seals/seals for lend which were stored in the archives and provided to individuals who did not possess a personal seal. ${ }^{90}$

From my point of view, serially produced seals can be excluded, as no motifs suitable for mass production are to be recognised among the most frequently attested seals in Artaxata. If this is the case, this leaves the interpretations as official seals and lending seals/seals for lend. In the context of the present study and with regards to the characterization of the archive the following must be stressed: neither the high number of official seals nor the presence of lending seals/seals for lend can be expected in a private context:

In the clearly private archives of Seleucia on the Tigris, we find a single seal used four times, one is preserved in three impressions, 23 were used twice and 229 occur in only one impression. ${ }^{91}$ In Aizanoi such concrete numbers are lacking, but seals attested in multiple impressions appear to be rare. ${ }^{92}$

This leads to a clear conclusion: the Artaxata archive is a public and thus official archive.

\section{Sealing at the Crossroads - Some general Remarks and Future Perspectives}

Besides the numbers, the iconography is important and there is a point that needs to be raised: Royal portraits on seals always have an official character, since the coins under the Hellenistic rulers bear their portraits. ${ }^{93}$ Khachatrian and Neverov tentatively identified some of the portrayed individuals on the seals from Artaxata. ${ }^{94}$

Besides the aforementioned seal with the image they interpreted as depiction of Cleopatra and Caesarion (Fig. 12) they proposed the identification of two other portraits of young men as Caesarion(Figs. 31, 32). There is, however, no basis for such a claim. Three seals are said to bear the portrait of Mithridates VI (Figs. 33-35) which is possible, but uncertain. Two portraits are identified as those of Polemon of Pontus (Figs. 36, 37) both of which are preserved in only one impression.

One portrait — identified as Iuba (Fig. 38) — is, in fact, a Ptolemaic king. ${ }^{95}$ We find a single impression of a seal with the portrait of an Armenian King, Tigranes II or Artavasdes II (Fig. 39). According to Neverov and Khachatrian, there are more Hellenistic kings to be found on the seals. ${ }^{96}$ One of these portraits we can name as Alexander (Fig. 40). Khachatrian and Neverov identify three Ptolemaic Queens as Isis on these seals (Figs. 41-43). In one portrait they would like to see Octavianus (Fig. 44) and in another Lepidus (Fig. 45). Five different portraits are identified as Octavia. ${ }^{97}$

\footnotetext{
89 E.g. Invernizzi et al. 2004, III: 50, No. M59.

90 Schreiber, forthcoming; cf. Plantzos 2018, 428.

91 McDowell 1935.

92 Berges 2010.

93 C.f. Schreiber, forthcoming; Kyrieleis 2015, 53-55.

94 Khachatrian - Neverov 2008, 249.

95 Cf. Kyrieleis 2015.

96 Khachatrian - Neverov 2008, no. 11. 13. 14. 18. 21-23.

97 Khachatrian - Neverov 2008, no. 44-47. 49.
} 
In some cases, Neverov and Khachatrian were driven by the idea, that the contemporary political context is reflected in the seals. ${ }^{98}$ This notion is not confined to their interpretation of the portraits, but also extends to other motifs. According to Neverov the Dionysian and Herculean themes for example are connected to Mark Anthony, cornucopiae refer to Cleopatra, Eros stands for Caisarion and so on. ${ }^{99}$

But, most of the motives are too generic to refer to a particular person and there is no need to strain the evidence: Even when discounting the portraits of which the designation is worth discussing, if not to reject, Artaxata's archive inventory with its rich repertoire of different motifs and portraits of individuals from different geographical areas, remains no less important. The "composition" of the archive's inventory underlines the political situation and the role of Artaxata as an economic and political centre (Fig. 46).

The most important questions - that can be answered by adequately processing the archive inventory - are: who used the seals? Are the Roman, Persian and Egyptian elements in the motif repertoire indicative of acts of imitation or, more generally, influence or do they point to a direct involvement by these parties? Did they send letters and contracts to Artaxata? - And what part of the entire inventory is indigenous Armenian? What is "Armenian" in Hellenistic times at all?

A more detailed study of the attested seals, which would take several months even with intensive study, can certainly lead to a more precise chronological delimitation and perhaps more detailed elaboration of the indications of the political and economic context indicated here and enable us to also answer more general questions. With 1,035 different motifs, a study of the attested seals will take a lot of time and effort, but it is worth it. Especially considering the number of seals found in multiple impressions and the other above outlined features of the seal impression inventory of Artaxata, it is highly probable that we are dealing with an official and not a private archive. Regarding the architectural and topographical context, we should always keep in mind that we are looking at reused material found in a dwelling built after the Roman destruction in 59 AD.

Artaxata also offers the chance of studying three archives - two from Hellenistic times and one from the Sassanian period. Such a study should definitely be undertaken in the future. There remains a gap in our evidence for archives in the late Hellenistic and early Roman times (Fig. 47). But people did not stop sealing documents or did they?

BIBLIOGRAPHY

Ariel, D. T., Naveh, J. (2003), Selected Inscribed Sealings from Kedesh in the Upper Galilee, BASOR 329: $61-80$.

Berges, D. (1997), Die Tonsiegel aus dem karthagischen Tempelarchiv, in: F. Rakob (ed.), Karthago 2. Die Deutschen Ausgrabungen in Karthago, Mainz.

98 Khachatrian - Neverov 2008, 251; Khachatrian 1996a, 367; Khachatrian 1996b, 222; Neverov 1996, $275-276$

99 Neverov 1996, 275-276. 
Berges, D. (2010), Ein königlich-pergamenischer Beamter in Aizanoi?, in: K. Rheidt (ed.), Aizanoi und Anatolien. Neue Entdeckungen zur Geschichte und Archäologie im Hochland des westlichen Kleinasien, Mainz: 38-43.

Berlin, A., Herbert, S. (2003), a New Administrative Center for Persian and Hellenistic Galilee: Preliminary Report of the University of Michigan-University of Minnesota Excavations at Kedesh, BASOR 329: 13-59.

Berlin, A., Herbert, S. (2012), Excavating Tel Kedesh: The Story of a Site and a Project, Archaeology 65: 24-29.

Boussac, M.-F. (1988), Sceaux déliens, Revue archéologique 2: 307-340.

Boussac, M.-F. (1992), Sceaux publics, Apollon, Helios, Arternis, Hecate, Les Sceaux de Délos I, Paris.

Boussac, M.-F., Invernizzi, A. (eds.) (1996), Archives et sceaux du monde hellénistique. Archivi e sigilli nel mondo ellenistico, Paris.

Coqueugniot, G. (2013), Archives et bibliothèques dans le monde grec. Édifices et organisation, Ve siècle avant notre ère-IIe siècle de notre ère, Oxford.

Harrauer, H., Lith, S. M. E. van (1978), Corpus Papyrorum Raineri 6: Griechische Texte 3, 1, Wien.

Instinsky, H. U. (1962), Die Siegel des Kaisers Augustus. Ein Kapitel zur Geschichte und Symbolik des antiken Herrschersiegels, Baden-Baden.

Invernizzi, A., Messina, V., Mollo, P., Bollati, A. (2004) Seleucia al Tigri. Le impronte di sigillo dagli archivi, vol. I-III, Alexandria.

Khachatrian, Z. (1996a), The Archives of Sealings Found at Artashat (Artaxata), in: M.-F. Boussac, A. Invernizzi (eds.), Archives et sceaux du monde hellénistique. Archivi e sigilli nel mondo ellenistico, Paris: $365-370$.

Khachatrian, Ž. D. (1996b), Les bulles à empreintes de sceaux d'Artachat, in: J. Santrot (ed.), Arménie. Trésors de l'Arménie ancienne, Musée Dobrée, Nantes, 22 mars-15 septembre 1996, Nantes: 222-226.

Khachatrian, Ž. (1998), Artaxata. Capitale dell'Armenia antica (II sec. a.C.-IV sec. d.C.), in: A. Invernizzi (ed.), Ai piedi dell'Ararat. Artaxata e l'Armenia ellenistico-romana, Turin: 97-158.

Khachatrian [Hačatrjan], Ž. D., Neverov, O. (2008), Arhivy stolicy drevnej Armenii Artašata [The Archives of Artashat-The Capital of Ancient Armenia], Erevan.

Killen, S. (2017), Parasema. Offizielle Symbole griechischer Poleis und Bundesstaaten, Wiesbaden.

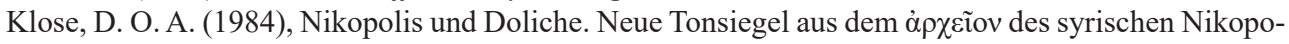
lis, Jahrbuch für Numismatik und Geldgeschichte 34: 63-76.

Kyrieleis, H. (2015), Hellenistische Herrscherporträts auf Siegelabdrücken aus Paphos, (Paphos IV B-Archäologische Forschungen 35), Wiesbaden.

Leriche, P. (1996), Le Chreophylakeion de Doura-Europos et la Mise en Place du Plan Hippodamien de la Ville, in: M.-F. Boussac, A. Invernizzi (eds.), Archives et sceaux du monde hellénistique. Archivi e sigilli nel mondo ellenistico, Paris: 157-169.

Lesperance, P. (2010), Symbols and Objects on the Sealings from Kedesh, Berlin.

Lilibaki-Akamati, M. (2011), The Archaeological Museum of Pella, Athina.

Lindström, G. (2003), Uruk. Siegelabdrücke auf hellenistischen Tonbullen und Tontafeln, (Ausgrabungen in Uruk-Warka. Endberichte), Mainz.

Maddoli, G. (1965), Le Cretule del Nomophylakion di Cirene, Annuario della Scuola archeologica di Atene e delle missioni italiane in Oriente 41-42: 39-145.

Manoukian, H. (1996), Les empreintes d'Artachate (antique Artaxata), in: M.-F. Boussac, A. Invernizzi (eds.), Archives et sceaux du monde hellénistique. Archivi e sigilli nel mondo ellenistico, Paris: 371-373.

McDowell, R. H. (1935), Stamped and Inscribed Objects from Seleucia on the Tigris, Ann Arbor.

Messina, V. (2006), Seleucia al Tigri. L'edificio degli archivi. Lo scavo e le fasi architettoniche, Florence. 
Messina, V. (forthcoming), Hellenistic Sealings in Context: The City Archive of Seleucia-on-the-Tigris, in: B. van Oppen, R. Wallenfels, Hellenistic Sealings and Archives: Proceedings of an International Conference 23-24 January 2018: Allard Pierson Museum, Amsterdam.

Mittag, P. F. (2006), Antiochos IV. Epiphanes. Eine politische Biographie, Berlin.

Neverov, O. (1996), Les Portraits sur les empreintes d'Artachate, in: M.-F. Boussac, A. Invernizzi (eds.), Archives et sceaux du monde hellénistique. Archivi e sigilli nel mondo ellenistico, Paris: 375-376.

Önal, M. (2018), Die Siegelabdrücke von Zeugma, (Dolichener und Kommagenische Forschungen 10 = Asia Minor Studien 85), Bonn.

Oppen, B. van, Wallenfels, R. (forthcoming), Hellenistic Sealings and Archives: Proceedings of an International Conference 23-24 January 2018. Allard Pierson Museum, Amsterdam.

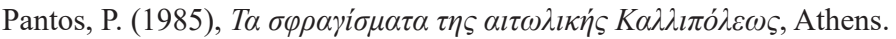

Plantzos, D. (1999), Hellenistic Engraved Gems, Oxford.

Plantzos, D. (2018), "For Good Ye Are and Bad, and Like to Coins": Why Bother with Seal-Impressions, in: P. P. Iossif, F. de Callatay, R. Veymers (eds.), Typoi. Greek and Roman Coins Seen Through Their Images. Noble Issuers, Humble Users?, Liége: 481-490.

Preka-Alexandris, K. (1996), a Group of Inscribed Seal Impressions of Thesprotia, Greece, in: M.-F. Boussac, A. Invernizzi (eds.), Archives et sceaux du monde hellénistique. Archivi e sigilli nel mondo ellenistico, Paris: 195-198.

Preka-Alexandris, K., Stoyas, Y. (2011), Economic and Socio-Political Glimpses from Gitana in Thesprotia: The Testimony of Stamped Amphora Handles, Coins and Clay Sealing, in: J.-L. Lamboley, M.-P. Castiglioni (eds.), L'Illyrie méridionale et l'Épire dans l'Antiquité - Actes du Ve colloque international de Grenoble (8-11 octobre 2008). Colloque International sur l'Illyrie Méridionale et l'Épire dans l'Antiquité, Paris: 663-683.

Rubensohn, O. (1907), Elephantine-Papyri, Berlin.

Salzmann, D. (1984), Porträtsiegel aus dem Nomophylakeion in Kyrene, BJ 184: 141-166.

Schreiber, T. (2016), Herrscher ohne Diadem oder ptolemäisches Zeitgesicht? - Zu den sogenannten Ptolemäerringen in der Sammlung des Archäologischen Museums der Westfälischen WilhelmsUniversität, Boreas 37-38: 227-283.

Schreiber, T. (2019a), Siegelabdrücke aus dem Archiv von Doliche. Die Arbeiten des Jahres 2018, e-Forschungsbericht des DAI, Faszikel, 1: 229-237.

Schreiber, T. (2019b), Urkundenverschlüsse mit Siegelabdrücken, in: M. Blömer, D. Çobanoğlu, E. Winter (eds.), Die Stadtgrabung in Doliche. Zu den Ergebnissen der Feldarbeiten 2015-2018, Istanbuler Mitteilungen 69: 155-160.

Schreiber, T. (forthcoming), Form und Funktion hellenistischer Siegel. Untersuchung auf Grundlage quantitativer und qualitativer Merkmale von Siegelabdrücken aus Archivkontexten.

Schreiber, T. (2020), In the Name of the King? New Considerations on the Classification of Seals from Hellenistic Archive Contexts, Parthica 22: 83-121.

Tonikian, A. V. (1992), The Layout of Artashat and its Historical Development, Mesopotamia 27: 161187.

Vandorpe, K. (1996), Seals in and on the Papyri of Greco-Roman and Byzantine Egypt, in: M.-F. Boussac, A. Invernizzi (eds.), Archives et sceaux du monde hellénistique. Archivi e sigilli nel mondo ellenistico, Paris: 231-291.

Weiß, P. (1992), Neue Tonsiegel von ,Doliche', Chiron 22: 171-193.

Winn Leith, M. J. (1998), Wadi Daliyah I: The Wadi Daliyeh Seal Impressions, (Discoveries in the Judaean Desert 24), Oxford.

Zardaryan, M. H. (2020), Study of the Classical sites of Armenia during the years of the Third Republic (1991-2018), Aramazd 10: 298-326.

Zoppi, C. (2011), L'Immagine di eracle con il toro nelle cretule di Selinunte punica, in: C. Lippolis, S. de Martino (eds.), Un impaziente desiderio di scorrere il mondo. Studi in onore di Antonio Invernizzi per il suo settantesimo compleanno, Firenze: 29-33. 


\section{Figures}

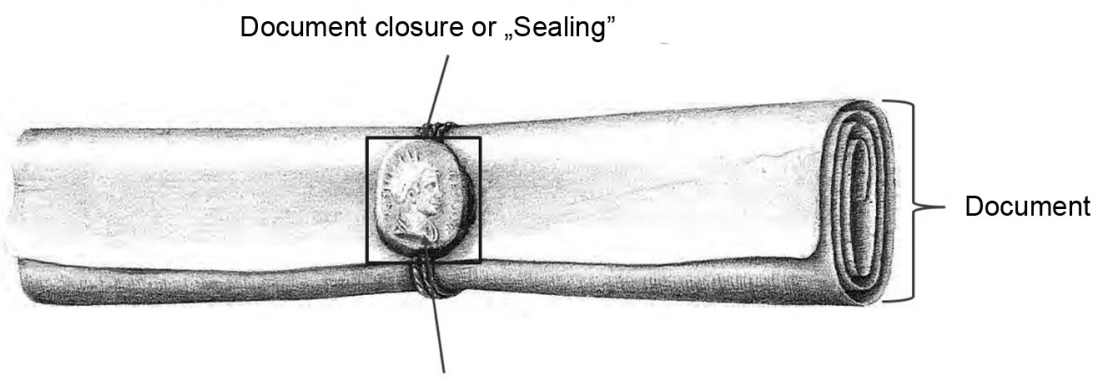

Seal impression on Sealing

Impression comes from a (lost) Seal

Fig. 1. Used terminology; T. Schreiber (After Lindström 2003, 10 fig. 2; Drawing by Helga Kosak; used with permission of Gunvor Lindström, German Archaeological Institute, Berlin)

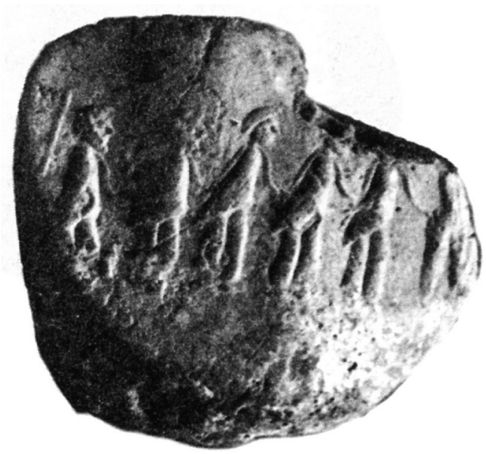

Fig. 2. Row of prisoners from a cylinder seal; Khachatrian - Neverov 2008, no. 92-9 


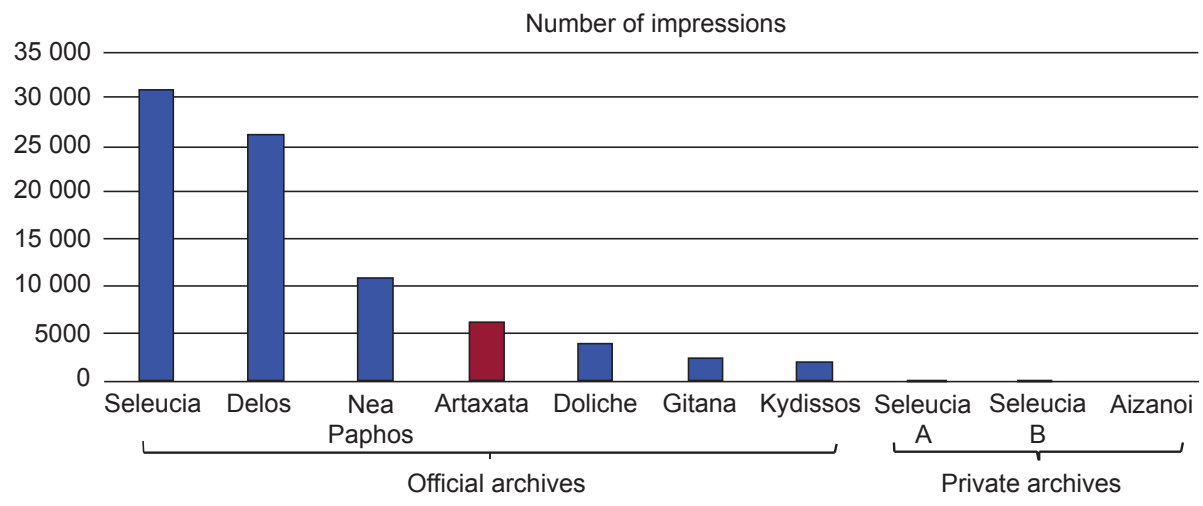

Fig. 3. Number of impressions from official and 'private' archives; T. Schreiber

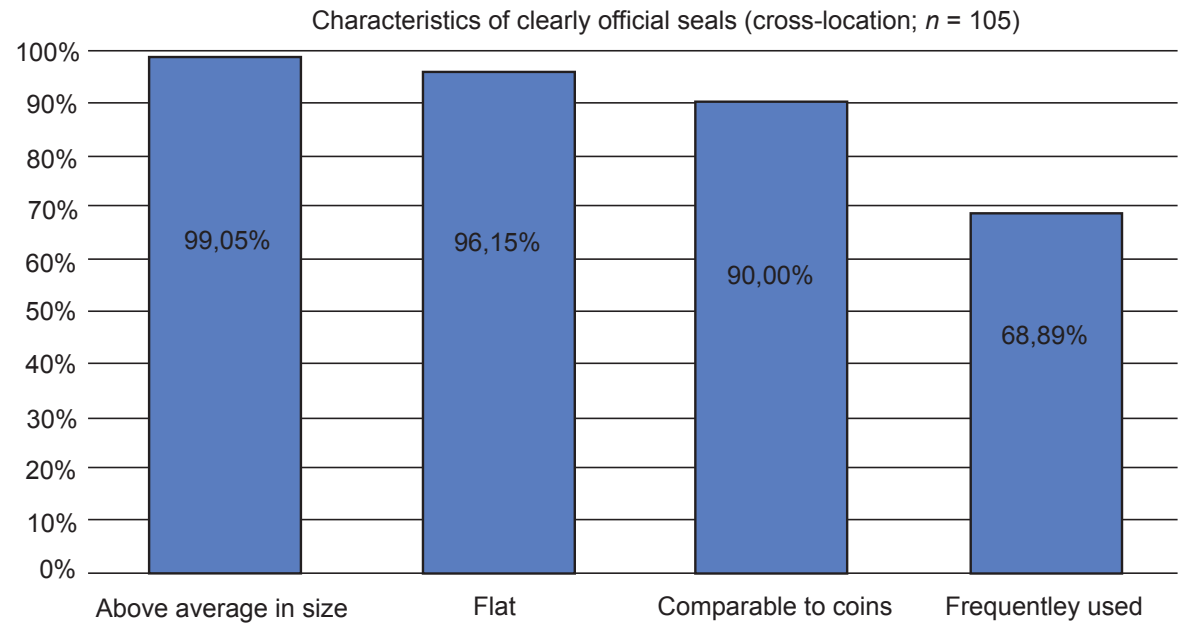

Fig. 4. Characteristics of clearly official seals; T. Schreiber 


\section{Distributions of themes on the Artaxata seals}

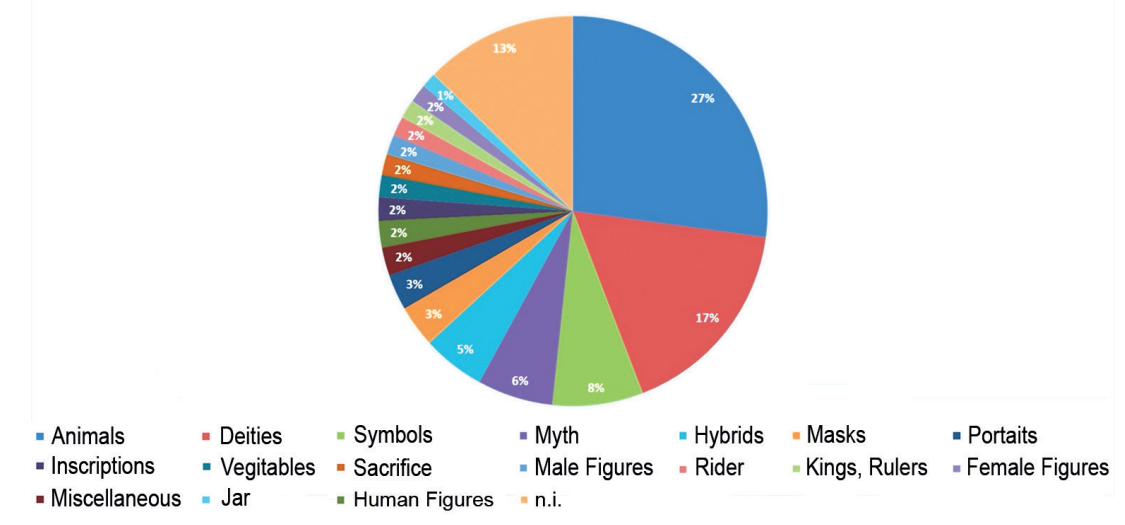

Fig. 5. Distributions of themes on the seals used in Artaxata; T. Schreiber

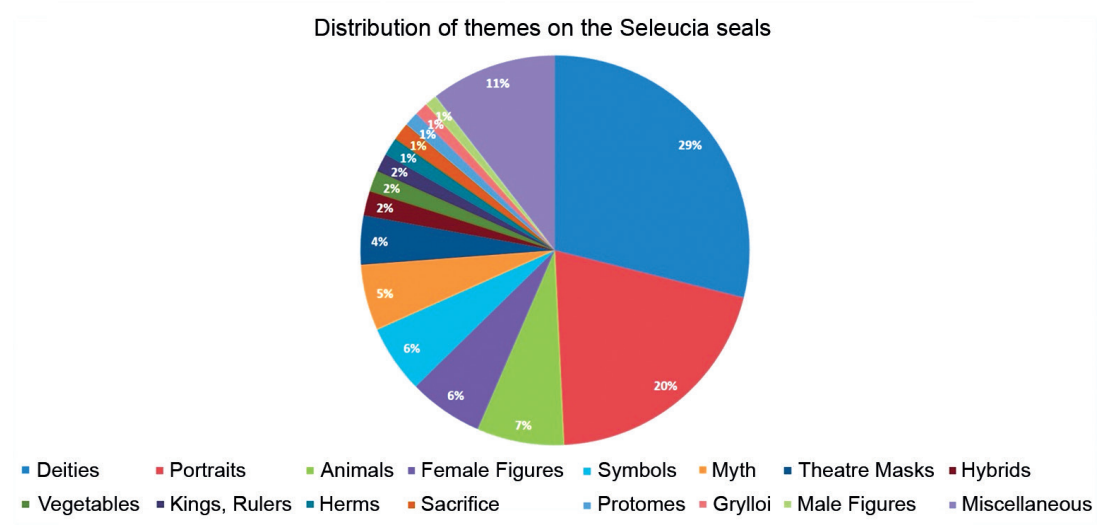

Fig. 6. Distributions of themes on the seals used in Seleucia on the Tigris (public archive);

T. Schreiber (after Invernizzi et al. 2004 I-III) 


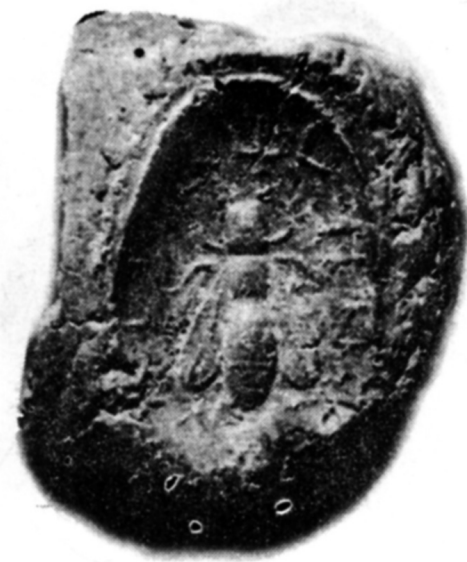

Fig. 7. Bee and Aramaic inscription; Khachatrian - Neverov 2008, no. 92-9
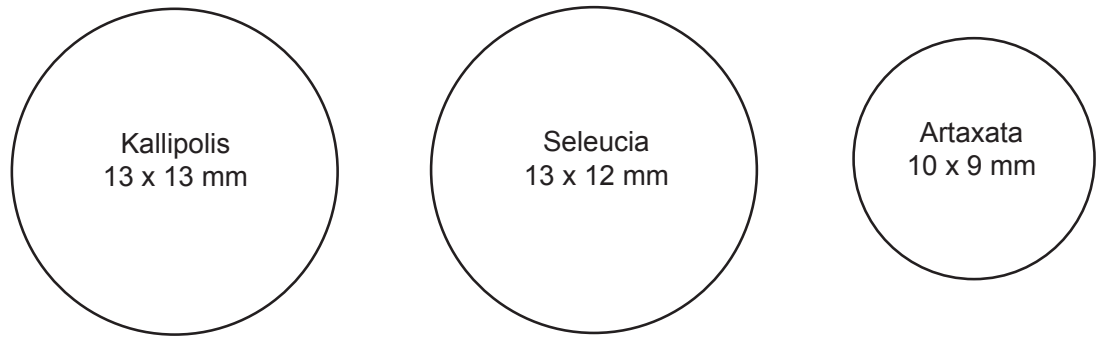

Fig. 8. Size of the seals used in Kallipolis, Seleucia and Artaxata; T. Schreiber 
Orchoi: flat and concave impressions ( $n=1007)$

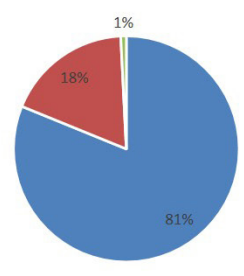

- flat I concave = ?

Kallipolis: flat and concave impressions $(n=329)$

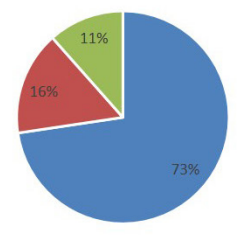

- flat - concave = ?
Cyrene: flat and concave impressions $(n=1122)$

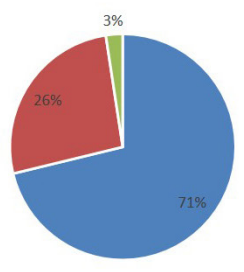

- flat - concave w?

Artaxata: flat and concave impressions $(n=1035)$

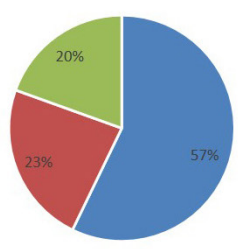

- flat I concave $\|$ ?

Fig. 9. Shares of flat and concave impressions from Uruk, Cyrene, Callipolis and Artaxata; T. Schreiber

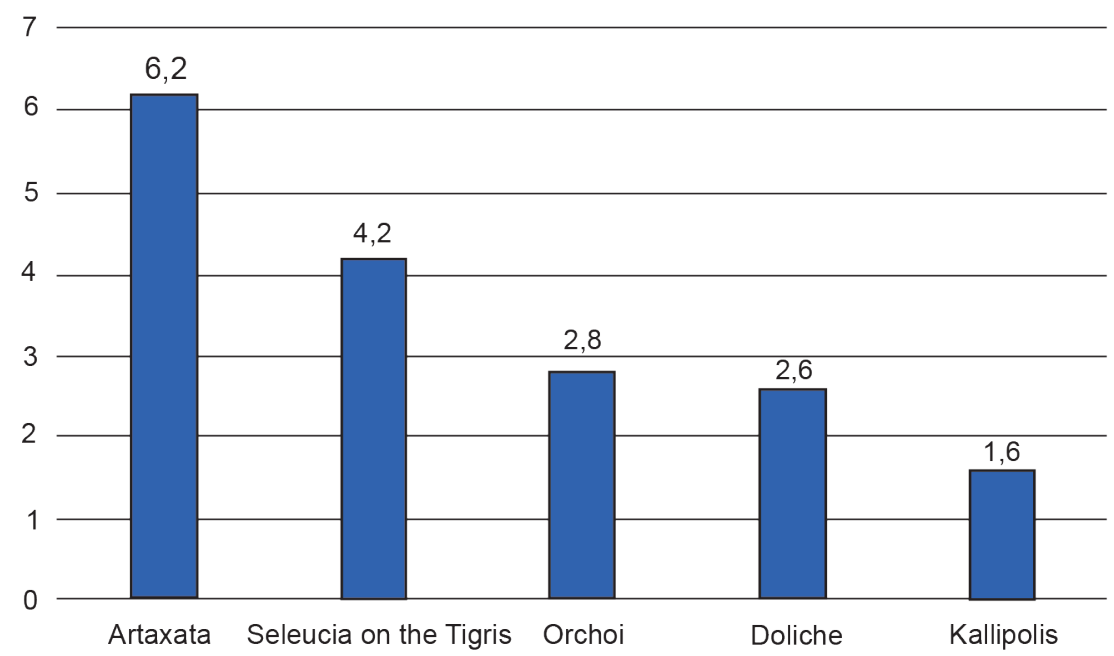

Fig. 10. Average frequency of impressions per seal; T. Schreiber 


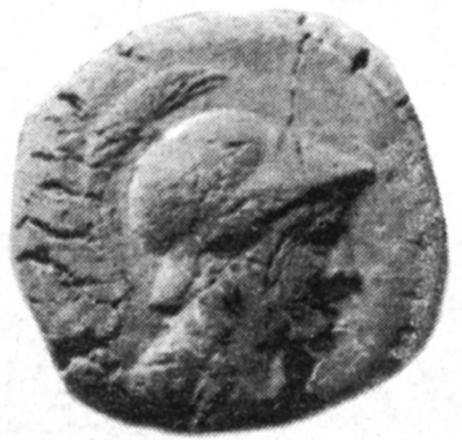

Fig. 11. Head of Athena; Khachatrian - Neverov 2008, no. 80-1

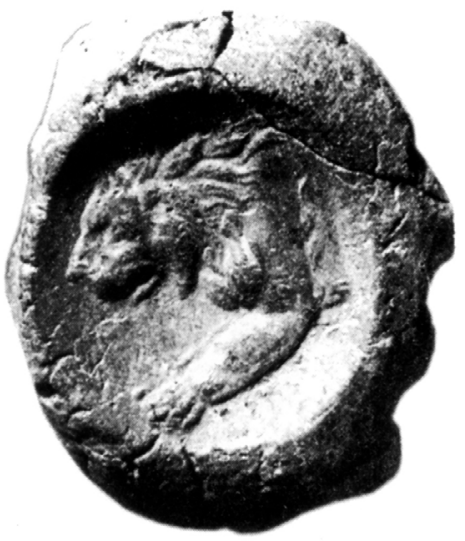

Fig. 12. Lion protome; Khachatrian - Neverov 2008, no. 501-44

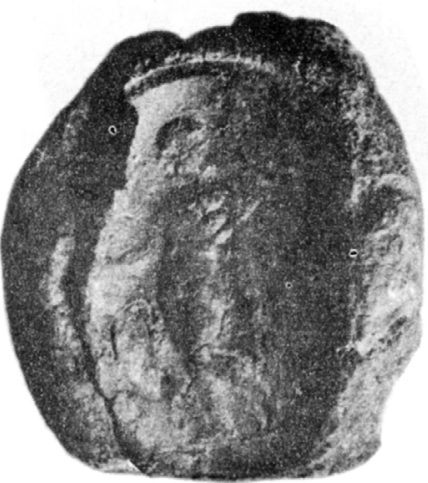

Fig. 13. Hermes; Khachatrian - Neverov 2008, no. 240-2 


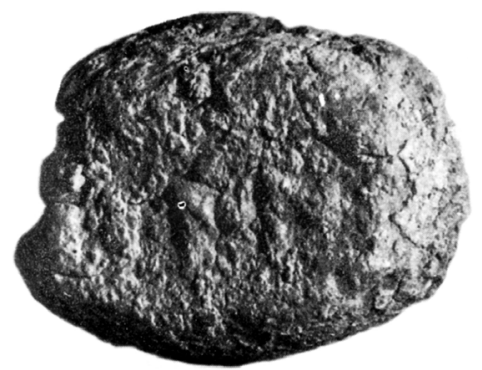

Fig. 14. Deers?; Khachatrian - Neverov 2008, no. 601

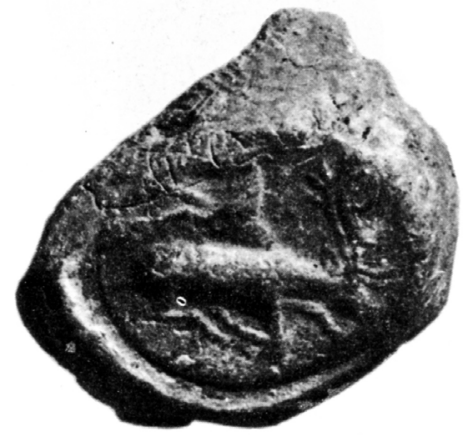

Fig. 15. Deer and Horse; Khachatrian - Neverov 2008, no. 599-6

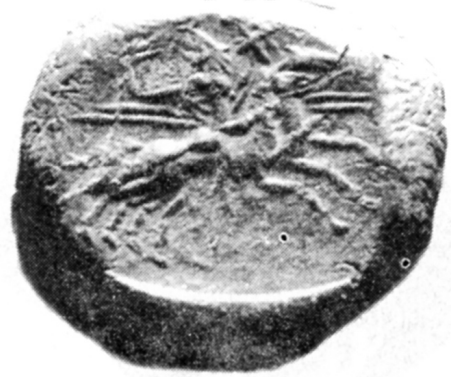

Fig. 16. Horseriders with spears; Khachatrian - Neverov 2008, no. 215-2a 


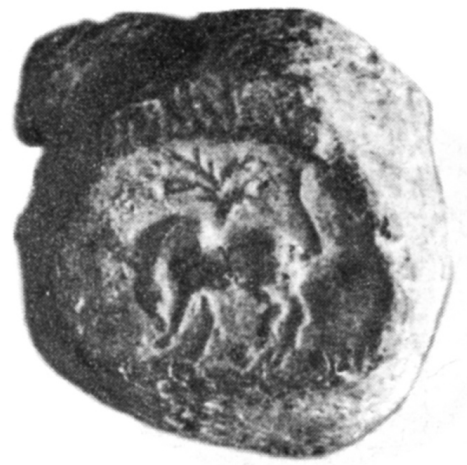

Fig. 17. Horse; Khachatrian - Neverov 2008, no. 558-2

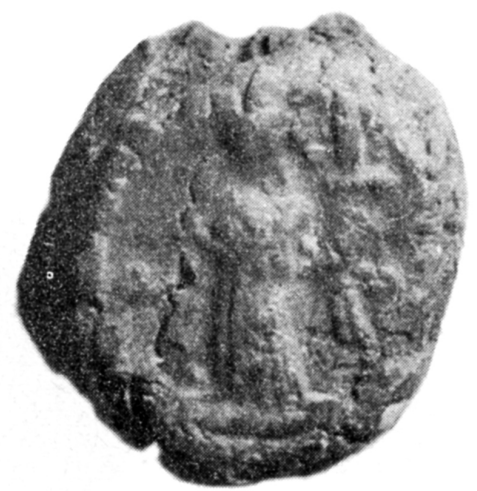

Fig. 18. Tyche; Khachatrian - Neverov 2008, no. 352-1

Share of the 10 most often used seals in Artaxata

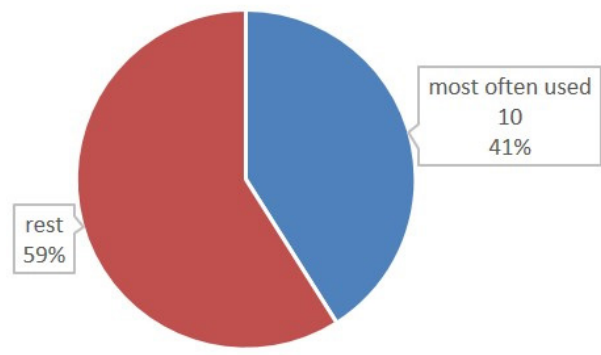

- most often used 10 - rest

Fig. 19. Share of the ten most often used seals in the Artaxata inventory; T. Schreiber 


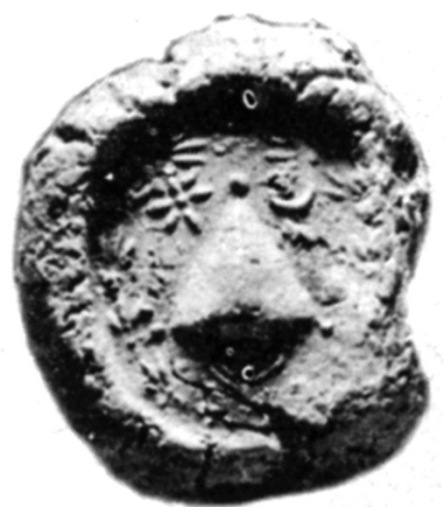

Fig. 20. Pilos; Khachatrian - Neverov 2008, no. 951-265

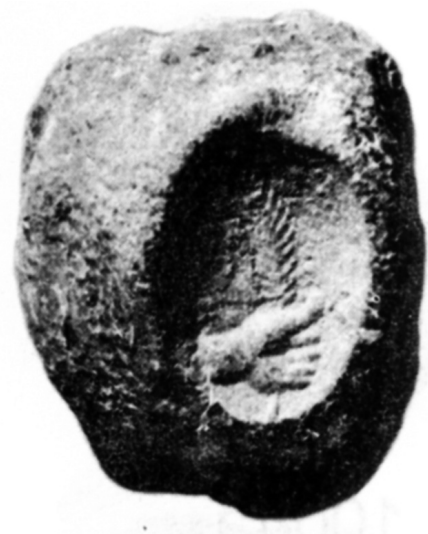

Fig. 21. Hand holding a grain; Khachatrian - Neverov 2008, no. 995-169

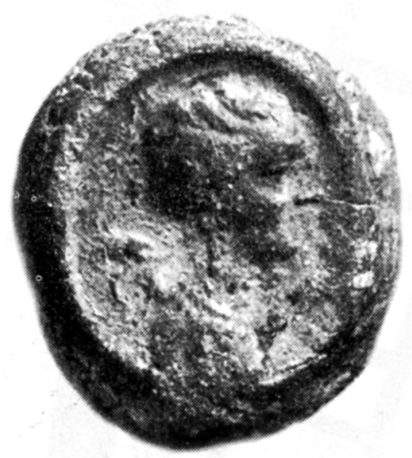

Fig. 22. Female bust to the right - "Cleopatra and Caesarion"; Khachatrian - Neverov 2008, no. $2-289$ 


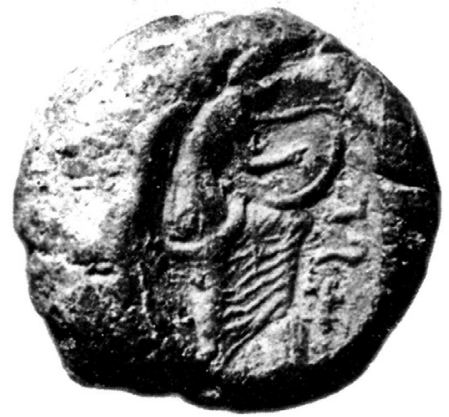

Fig. 23. Nike writing on a shield; Khachatrian - Neverov 2008, no. 372-249

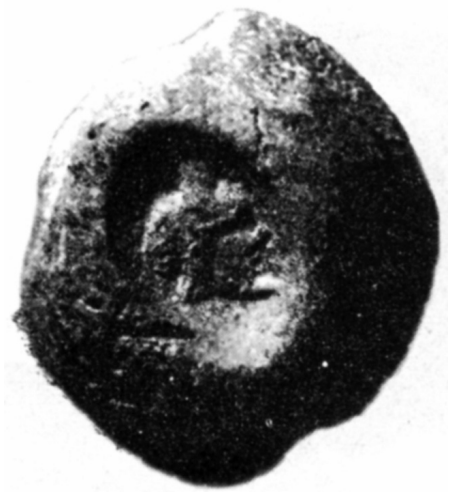

Fig. 24. Theatre mask; Khachatrian - Neverov 2008, no. 454-217

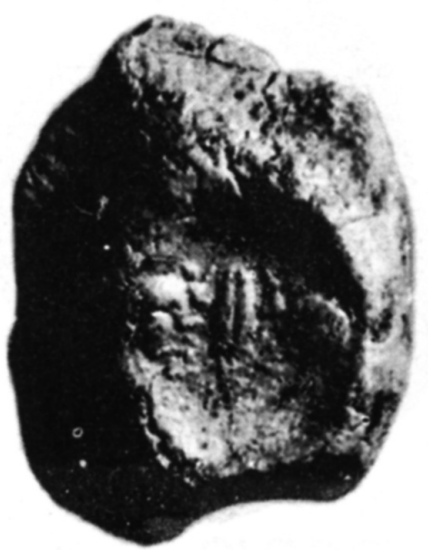

Fig. 25. Two mice on a ear grain; Khachatrian - Neverov 2008, no. 915-182 


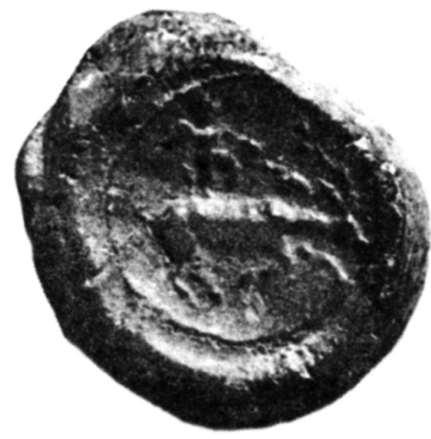

Fig. 26. Eros on a deer; Khachatrian - Neverov 2008, no. 174-1

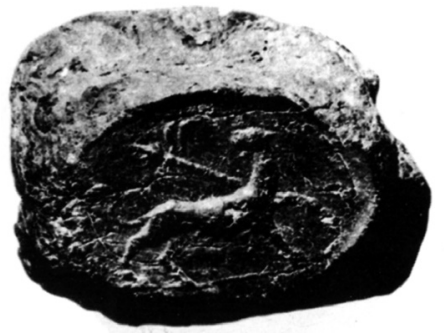

Fig. 27. Panther and a thyrsus; Khachatrian - Neverov 2008, no. 894-45

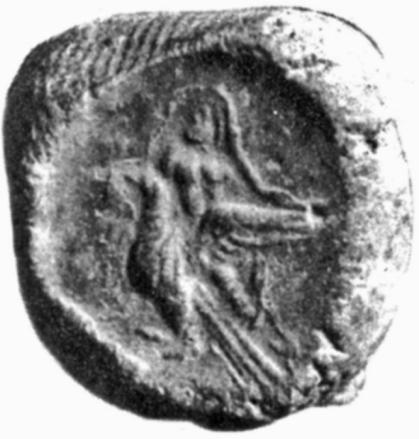

Fig. 28. Abduction of Ganymede; Khachatrian - Neverov 2008, no. 160-2 


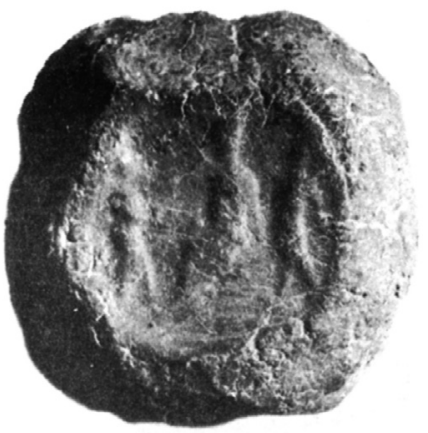

Fig. 29. King(?) on a throne; Khachatrian - Neverov 2008, no. 127

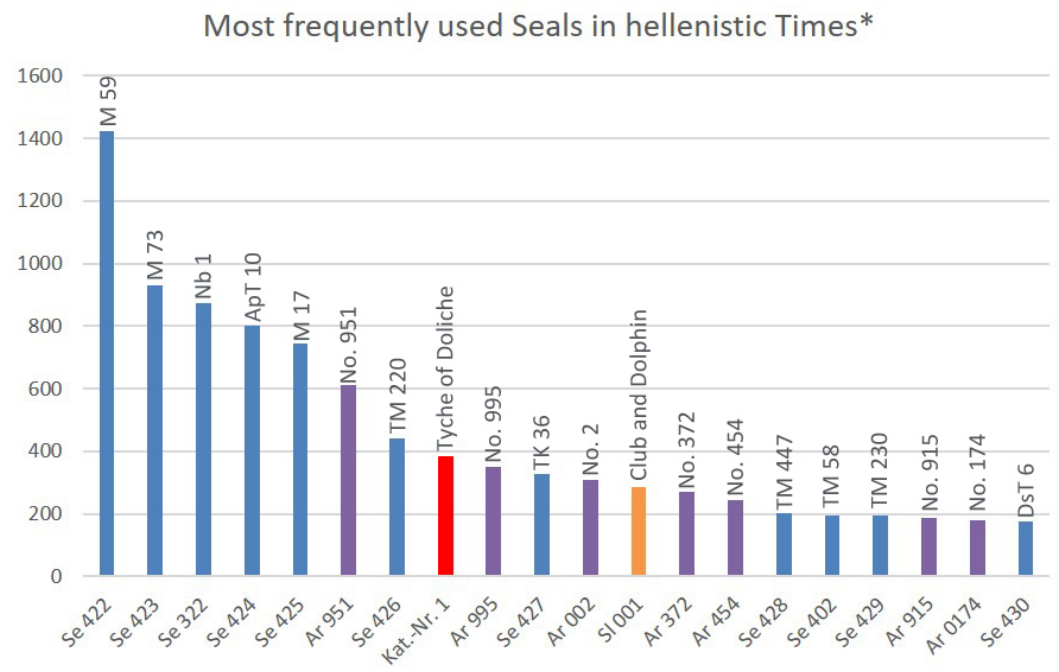

Seleucia on the Tigris (after Invernizzi et al. 2004 I-III)

Artaxata (after Khachatrian - Neverov 2008)

Doliche

Selinus

*counted in: Seleucia, Doliche, Kydissos, Orchoi, Artaxata, Kallipolis + all accessible seal impressions / seals

Fig. 30. Most often used seals; T. Schreiber 


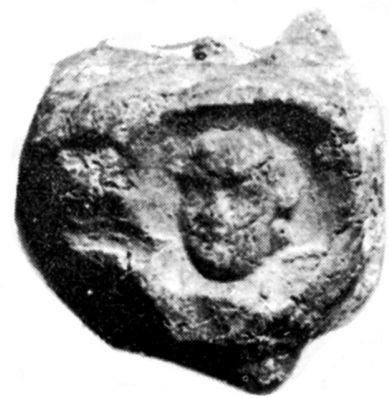

Fig. 31. Eros - "Caesarion"; Khachatrian - Neverov 2008, no. 3-1

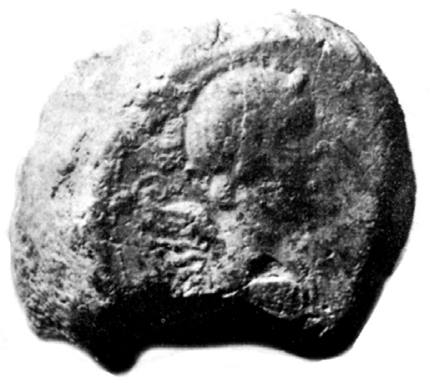

Fig. 32. Bust of a youth - "Caesarion"; Khachatrian - Neverov 2008, no. 454-217

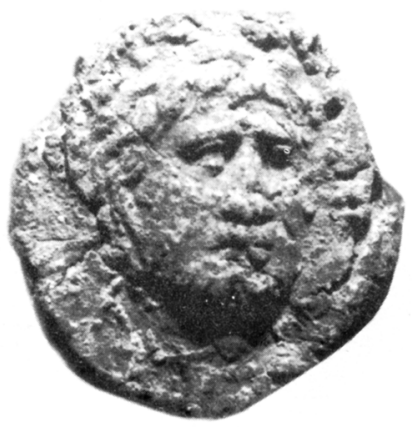

Fig. 33. Mithridates VI (?); Khachatrian - Neverov 2008, no. 5-1 


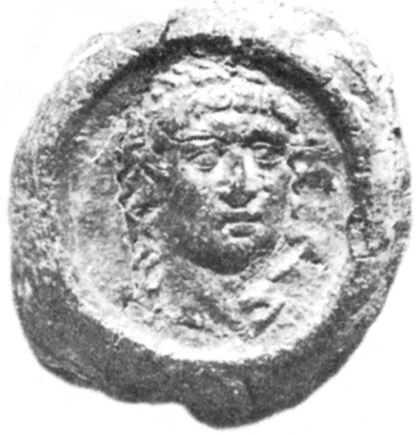

Fig. 34. Mithridates VI (?); Khachatrian - Neverov 2008, no. 6-1

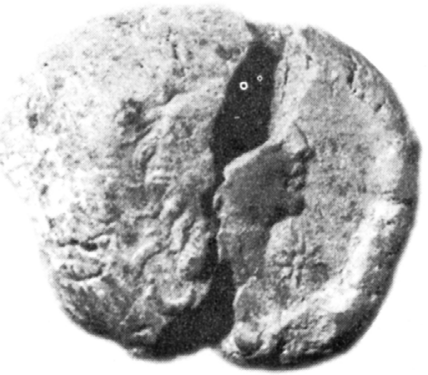

Fig. 35. Mithridates VI (?); Khachatrian - Neverov 2008, no. 7

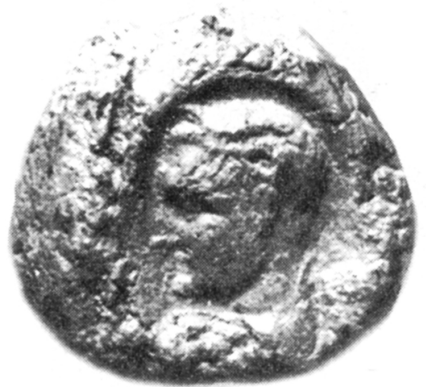

Fig. 36. "Polemon"; Khachatrian - Neverov 2008, no. 9 


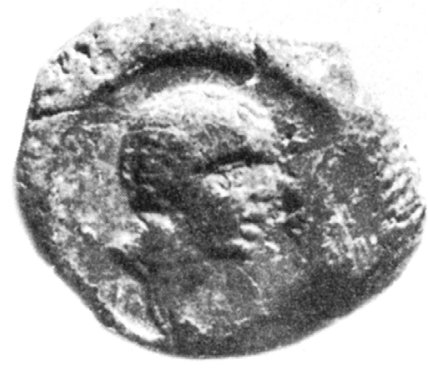

Fig. 37. "Polemon"; Khachatrian - Neverov 2008, no. 10

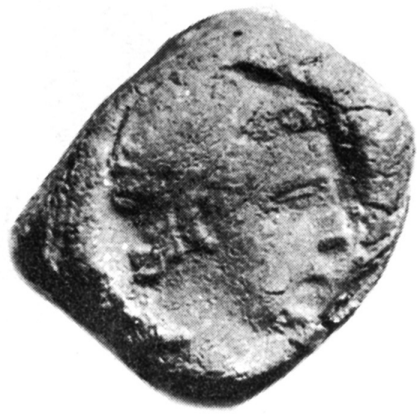

Fig. 38. Ptolemaic King - "Iuba"; Khachatrian - Neverov 2008, no. 12

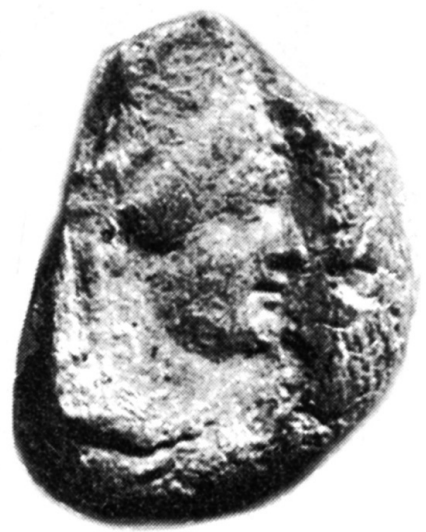

Fig. 39. Armenian King; Khachatrian - Neverov 2008, no. 16 


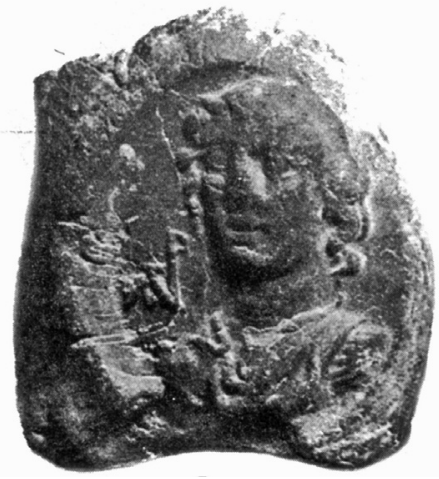

Fig. 40. Alexander; Khachatrian - Neverov 2008, no. 8

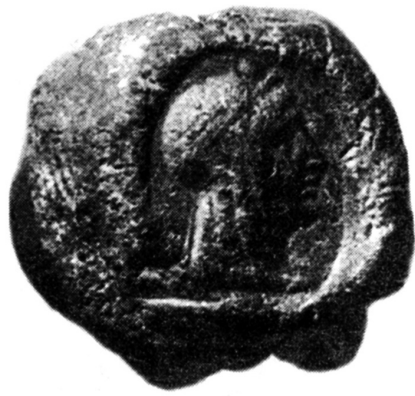

Fig. 41. "Cleopatra Thea"; Khachatrian - Neverov 2008, no. 39

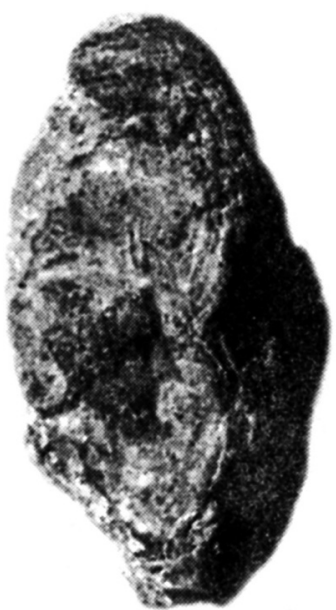

Fig. 42. "Cleopatra VII"; Khachatrian - Neverov 2008, no. 40 


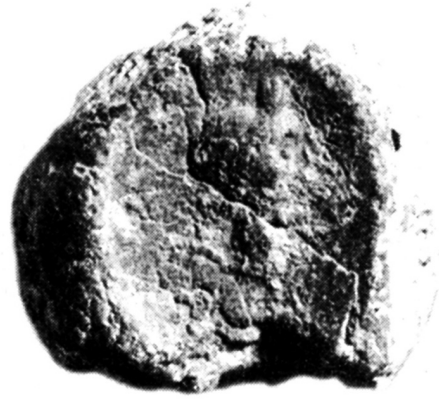

Fig. 43. "Cleopatra VII"; Khachatrian - Neverov 2008, no. 41

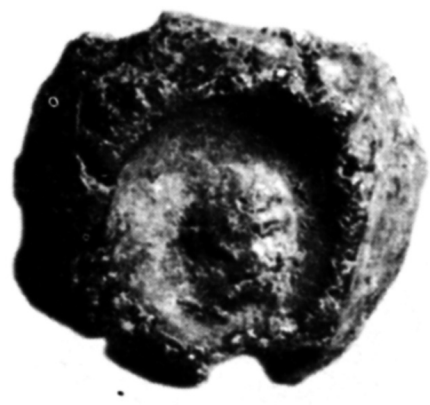

Fig. 44. "Octavianus"; Khachatrian - Neverov 2008, no. 25

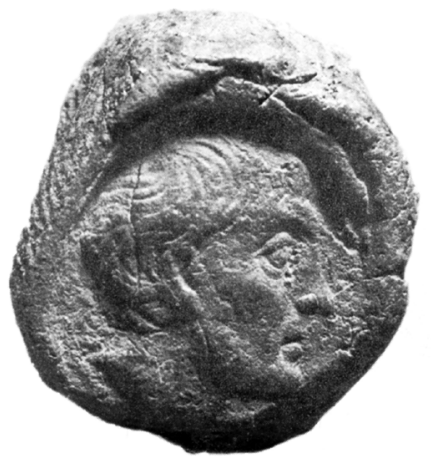

Fig. 45. "Lepidus"; Khachatrian - Neverov 2008, no. 34-1 


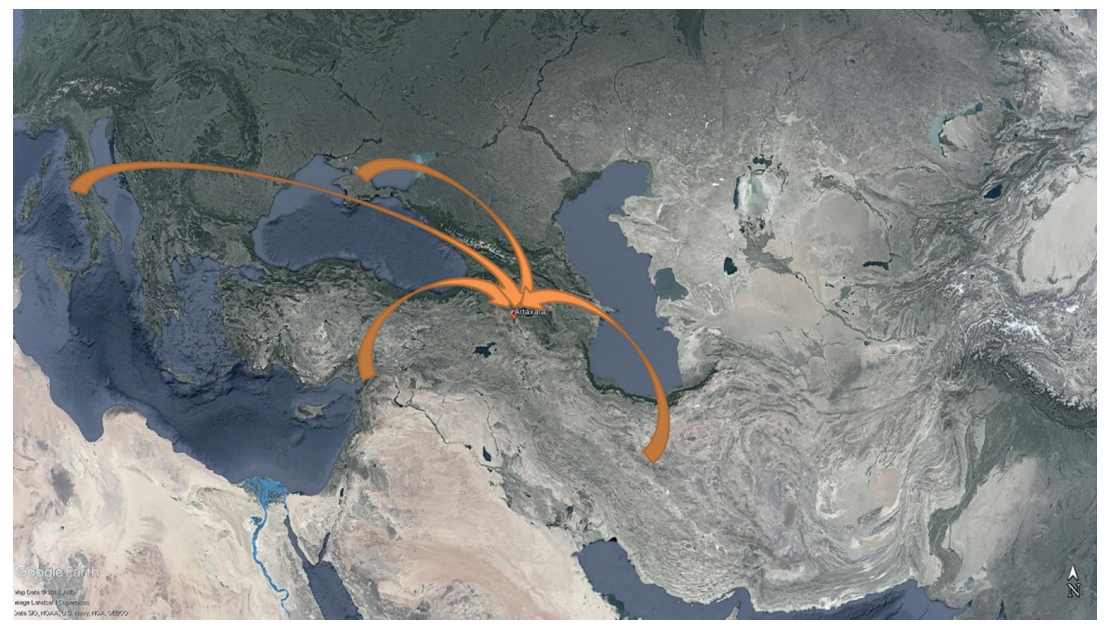

Fig. 46. Different regional influences recognisable in the archive's inventory; T. Schreiber

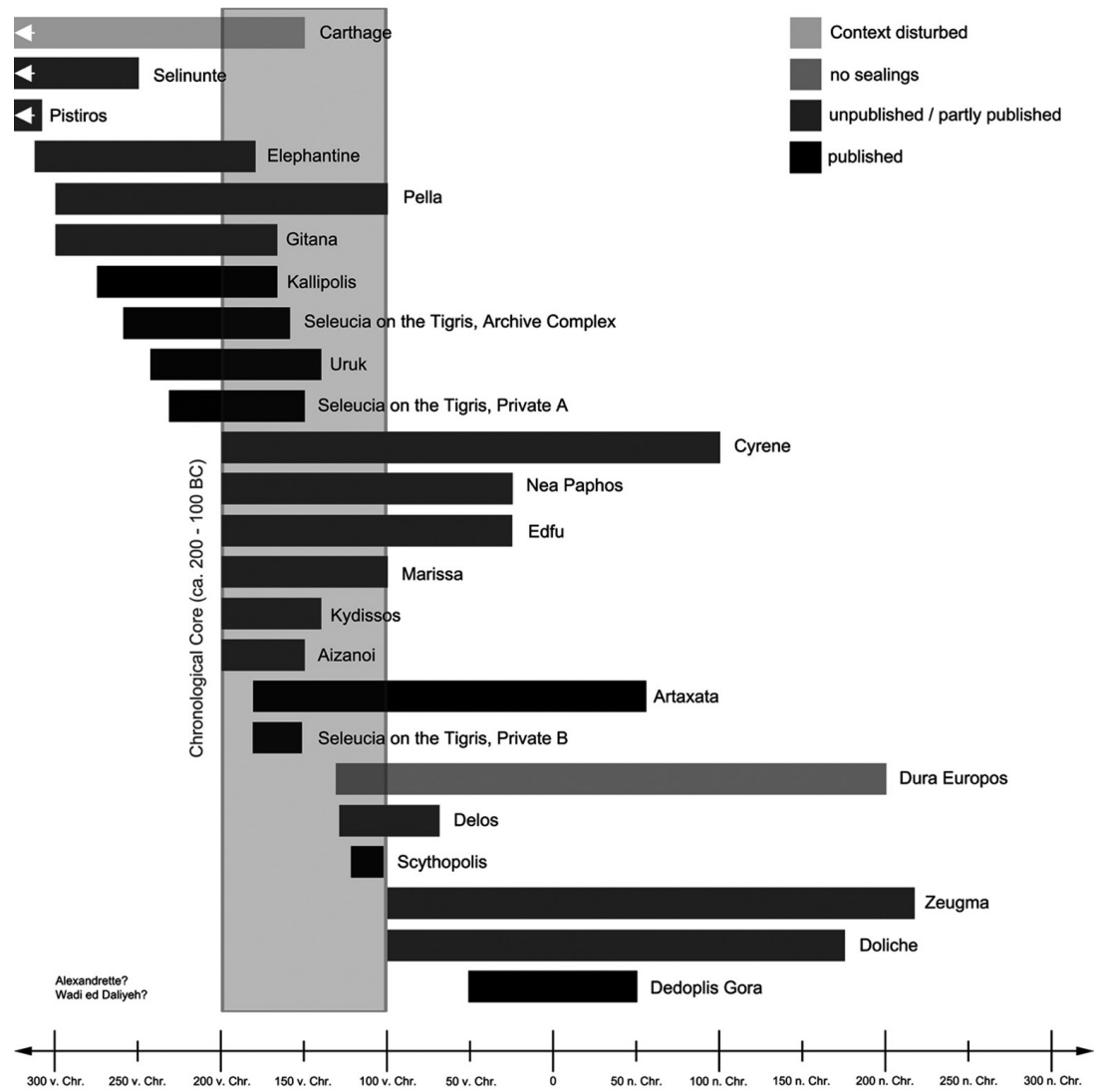

Fig. 47. Timeline of Hellenistic/Roman archives; T. Schreiber 


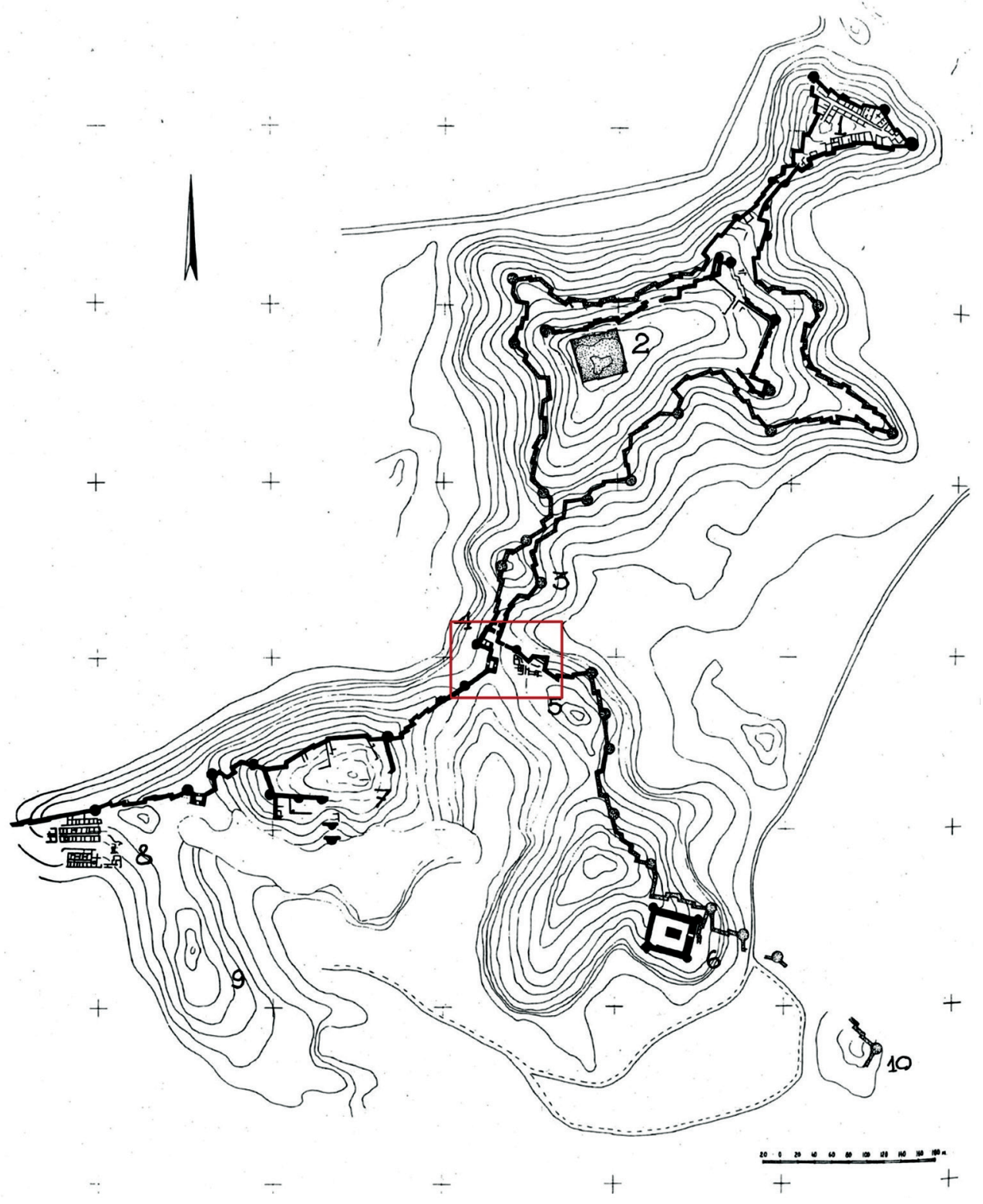

Map 1. Artaxata — the central group of Hills; Tonikian 1992, 176 fig. C 


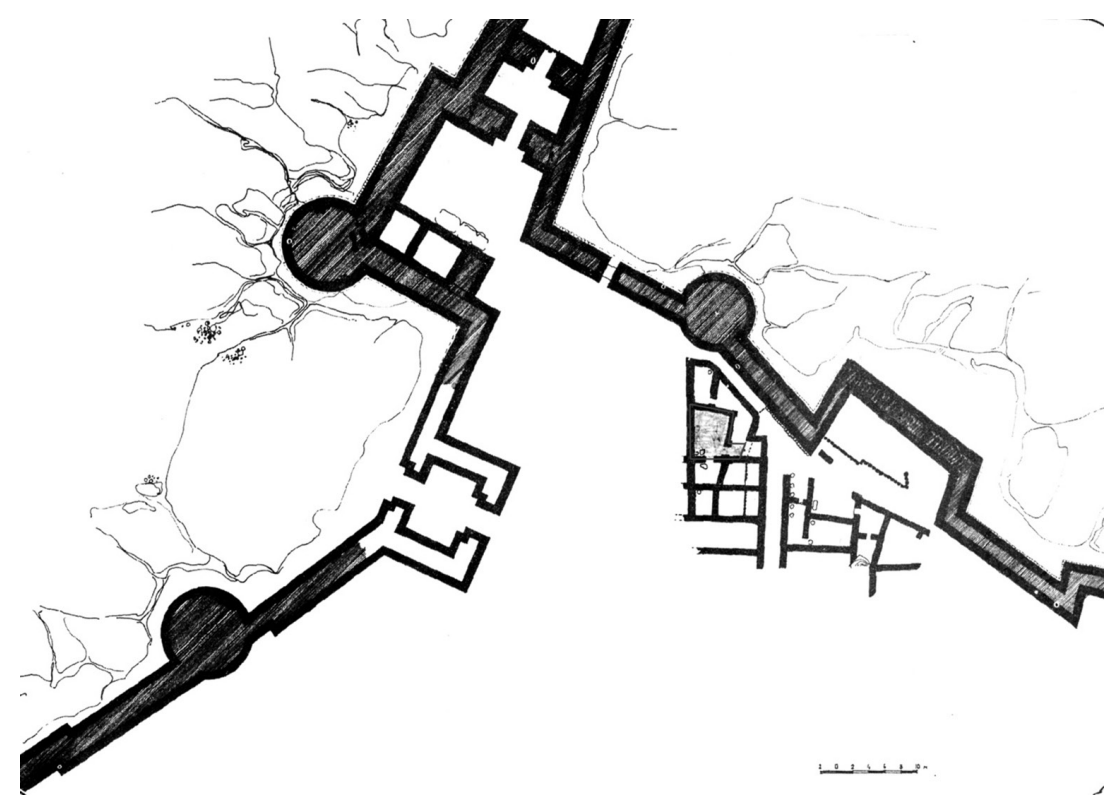

Map 2. Hill V; Khachatrian - Neverov 2008, pl. 2

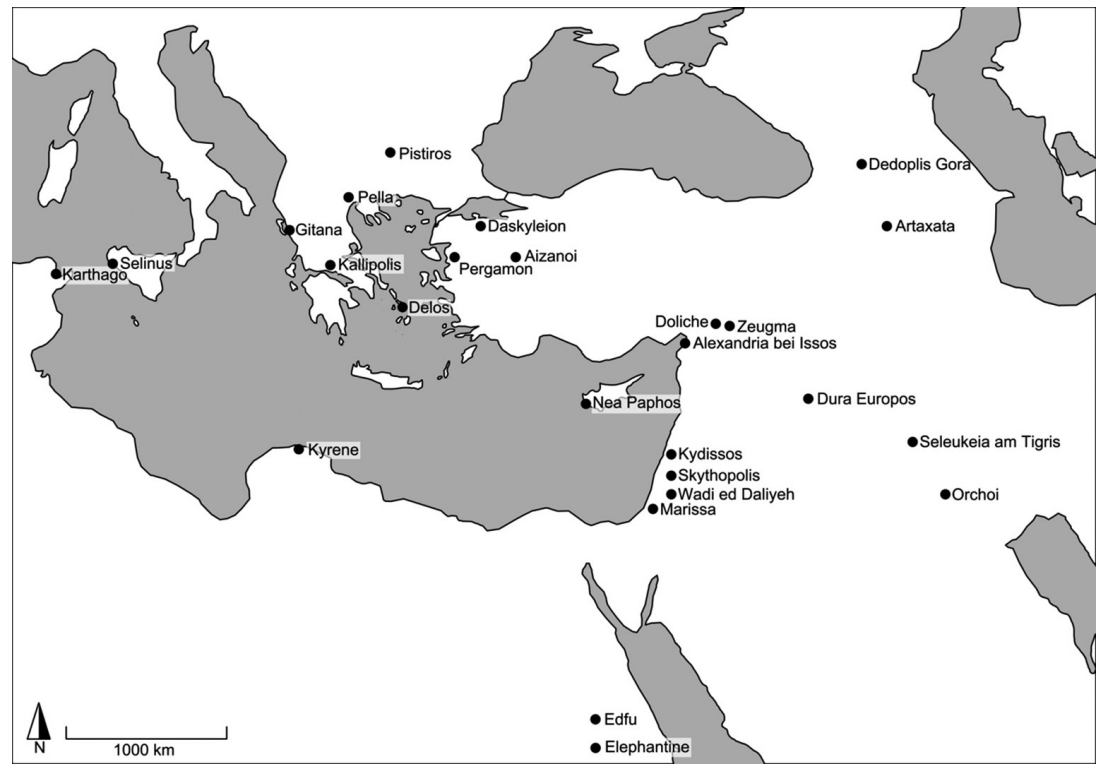

Map 3. Map of the Hellenistic and Roman archives; T. Schreiber 